\title{
Labour Market Outcomes:
}

\author{
A Cross-National Study
}

CILN is a collaberative research venture between the Social Sciences and Humanities Research Council (SSHRC) and McMaster University. Additional funding is provided by the University of British Columbia, the University of Toronto, Queen's University, York University and Human Resources Development Canada (HRDC).

McMaster University

DEPARTMENT OF ECONOMICS 
THE MEASUREMENT OF UNEMPLOYMENT: AN EMPIRICAL APPROACH

By STEPHEN R. G. JONES AND W. CRAIG RIDDELL ${ }^{1}$

February 1994

Revised October 1996

Final Revision February 1998 


\section{HEADNOTE}

Although the unemployment rate is one of the most widely cited and closely monitored economic statistics, the definition and measurement of unemployment remain controversial. An important issue is whether non-employed persons who display a marginal attachment to the labor force (for example, those who are available for and desire work but are not searching for work) should be classified as unemployed or non-participants. Although this issue has been extensively debated, it has never been tested empirically. This paper carries out empirical tests of this and related hypotheses using a unique longitudinal data set from Canada.

We find within the marginally attached a "waiting" group whose behavior indicates that they would be more appropriately classified as unemployed rather than out-of-the-labor force. The remainder of the marginally attached exhibit behavior between that of the unemployed and the balance of non-participants, suggesting that the desire for work among non-searchers conveys substantial information about labor force attachment and future employment status. Our methods also

apply to heterogeneity within the unemployed, and we investigate behavioral variation linked to differences in job search methods and reasons for entry into unemployment. Although those using "passive" job search do exhibit behavior somewhat distinct from "active" searchers, our results reject the practice of classifying passive job searchers as out-of-the-labor force.

Overall, our results indicate that the non-employed are very heterogeneous, so that any single division into "unemployment" and "out-of-the-labor force" is unlikely to fully capture the variety of degrees of labor force attachment. 


\section{INTRODUCTION}

THE UNEMPLOYMENT RATE and labor force participation rate are two of the most widely cited and closely monitored economic statistics. Yet the definition of unemployment, and the associated definition of participation, remain controversial. $^{2}$ For the non-employed, many countries base the distinction between unemployment (U) and out-of-thelabor force $(\mathrm{O})$ primarily on job search. ${ }^{3}$ However, the behavior of some non-searchers suggests that they are attached to the labor force, and thus should perhaps be measured as U. For example, there has been considerable debate about whether to classify "discouraged workers"- those who indicate that they want work but did not search because they believe no work is available—as U or O (National Commission on Employment and Unemployment Statistics, 1979; OECD, 1987, 1995). At the same time, some forms of job search are less intensive than others, and in terms of their labor force attachment some searchers may be more appropriately classified as $\mathrm{O}$.

The difficult nature of these measurement questions is illustrated by differences in criteria across countries and over time within countries. For example, the United States classifies as O those who employ only "passive" methods of job search—for example, looking at job ads—while Canada and many other OECD countries include both "passive" and "active" searchers among the unemployed (Stein, 1967; Zagorsky, 1996). On the other hand, discouraged workers were classified as U in the US prior to 1967 and in Canada prior to 1975 but have subsequently been included in the "out-of-the-labor force" category.

Much economic analysis is based on the $\mathrm{U}$ versus $\mathrm{O}$ distinction, with those classified as $\mathrm{U}$ often modeled as being engaged in optimal search behavior, and those classified as $\mathrm{O}$ as being engaged in household production. However, as discussed by Hall (1970) and Clark and Summers (1979), a variety of evidence suggests that the U versus $\mathrm{O}$ distinction may often be arbitrary and ambiguous. Many individuals display multiple changes of classification within a non-employment spell, with repeated spells of U separated by brief spells of labor force withdrawal. Furthermore, the experience of statistical agencies suggests that the division of the non-employed into participants and nonparticipants is quite sensitive to questionnaire design and respondents' circumstances. ${ }^{4}$ Perhaps the strongest evidence of this sensitivity comes from the US Current Population Survey (CPS) Reinterview Program, in which a subsample of respondents are reinterviewed about their labor force activities. Although these interviews are separated by only one week (the questions apply to the same period), substantial differences in classification result (Abowd and Zellner, 1985; Poterba and Summers, 1986). Others have questioned whether the response to the job search question is likely to be meaningful in the absence of related questions about acceptable job characteristics, especially the wage (Lucas and 
Rapping, 1969). Nonetheless, it remains the case that most models of labor market behavior treat those classified as $\mathrm{U}$ as being willing to work at the market wage (and thus at an interior solution in terms of desired hours of work) while those classified as $\mathrm{O}$ are modeled as being at a corner solution, and thus requiring a higher offered wage to entice them into the labor market. ${ }^{5}$

A related issue is whether "waiting" may be, in some circumstances, a productive activity in terms of obtaining employment (Hall, 1983). For example, the newly unemployed have a stock of job vacancies to search through and apply for. Those who do not obtain a match from this initial stock may experience periods of waiting for new openings and for responses to applications made previously. As noted by Blanchard and Diamond (1992, p. 355), in flow models of the labor market in which separations arise from job destruction, "'waiting' is a more descriptive term than 'searching'." Similarly, in segmented labor market models such as those developed by Hall (1975), McDonald and Solow (1985), Bulow and Summers (1986) and Jones (1987), individuals may queue for primary sector jobs rather than take available employment in the secondary sector. Although modelers refer to this behavior as "wait" or "transitional" unemployment, in the absence of job search such individuals would be classified as O. ${ }^{6}$

The criteria for distinguishing $\mathrm{U}$ and $\mathrm{O}$ also play a role in the persistence of unemployment, a phenomenon that has received much attention in macroeconomics. In particular, the pro-cyclical behavior of participation contributes to unemployment persistence over the cycle. Owing to labor force withdrawal, measured unemployment rises more slowly in recessions than would be expected on the basis of the change in employment. Similarly, unemployment declines slowly during the subsequent expansion as non-participants return to the labor force.

Most of the policy debate regarding the definition of unemployment has centred on whether "discouraged workers" or even all those desiring but not searching for work should be counted as unemployed or non-participants. However, the debate has been largely carried out on a priori grounds (such as what actions should be regarded as evidence of strong labor force attachment) or on the basis of comparisons of the characteristics of the different groups at a point in time (OECD, 1987, 1995). This paper provides an empirical assessment of the appropriate definitions of unemployment and non-participation by testing whether some individuals conventionally classified as $\mathrm{O}$ are behaviorally distinct from the unemployed. Particular attention is given to those who are not searching for work but state that they want work, a group referred to as the "marginally attached." We also investigate the behavior of subsets of this group, such as discouraged workers and a group whose activities can be characterized as "waiting." In addition, 
we test whether some of those classified as $U$ in most countries-including a group using "passive" search methods_-are behaviorally distinct from active searchers and from non-participants.

These issues are quantitatively important and may thus affect one's views about the amount of underutilization of labor in the economy or the extent of frictional and structural mismatch. Those who desire work but are not searching for it are a small proportion of non-participants but constitute a large number relative to the unemployed. In our data, such individuals constitute 25 to $35 \%$ of $U$ so that including the marginally attached among the unemployed would raise the current Canadian unemployment rate from about 9 to 11 or 12 percent. Canadians whose sole search method is "looked at ads" constitute about 5 to 6 percent of U; removing these individuals to make the Canadian unemployment rate comparable to the US measure lowers the current Canadian rate by approximately 0.7 percentage points (Zagorsky, 1996). Furthermore, the criteria for distinguishing between $U$ and O affect not only the level of the unemployment (and participation) rate but also the duration of $\mathrm{U}$ and $\mathrm{O}$ spells and the number of transitions between states. As noted by Clark and Summers (1979), many spells of unemployment end in withdrawal from the labor force as conventionally measured. Sequences of non-employment spells such as $E \rightarrow U \rightarrow O \rightarrow U \rightarrow E$ and $E \rightarrow U \rightarrow O \rightarrow E$ are recorded as involving short periods of unemployment interrupted by a period of labor force withdrawal, but could be viewed as one longer period of "unemployment" broadly defined. Differences across age and sex groups in both the incidence and average duration of unemployment are quite sensitive to the choice between these narrow and broad definitions. In addition, subtler issues—-such as evidence relating to state dependence in unemployment spells—may be affected by these measurement criteria.

Diversity in the degree of labor force attachment presents a challenge for measurement. For both analytical purposes and public understanding of economic developments, there is a need to truncate the underlying distribution of labor force attachment into a small number of categories. A principal objective of this paper is to examine the adequacy of the job search requirement for this purpose, and whether alternatives such as the desire for work should replace or supplement the conventional criteria. $^{7}$

\section{BACKGROUND}

A statistical framework for utilizing longitudinal data to test whether two (or more) non-employment states are behaviorally distinct was proposed by Flinn and Heckman (1983). Using the NLSY, they test whether unemployment and out of the labor force are distinct states for white male high school graduates. Gönül (1992) extends 
this analysis to a broader group of male and female youths, and Tano (1991) tests the equivalence of U and O for both youths and adults using the CPS gross flows data. In the data sets used by these authors, only the states E, U and O are observed. ${ }^{8}$ For the working age population as a whole, the $\mathrm{O}$ category contains many individuals with little or no labor force attachment, such as full time students, the retired and those engaged in work within the home. There is little doubt that the behavior of many in this group is distinct from that of the unemployed. The key measurement and policy questions — such as whether unemployment should be defined as requiring active job search, any job search, or

the desire for work-relate to subsets of the $\mathrm{O}$ and $\mathrm{U}$ categories, such as non-searchers who report that they desire work, or those using "passive" search methods. Empirical testing of these questions requires data in which search methods and the desire for work are identified. No existing longitudinal data sets have these features. ${ }^{9}$

This research employs a special longitudinal data set created by matching the cross-sectional Survey of Job Opportunities (which measures a variety of categories of marginal attachment as well as search methods of the unemployed) with the subsequent month of the Labour Force Survey (LFS). This matching utilizes the fact that about $5 / 6$ of the respondents to the LFS are common to contiguous months. Since the SJO is a supplement to the LFS, it is therefore possible to create matched files for each year in which the SJO was carried out. ${ }^{10}$

\section{STATISTICAL FRAMEWORK}

Our empirical analysis of the appropriate definition of unemployment can be described in the context of a Markov model of transitions among labor force states. For expository purposes we first examine heterogeneity within the $\mathrm{O}$ category by allowing for four states: employment (E), unemployment (U), marginal attachment (M), and notattached-to-the-labor force (N). The first two states correspond to those conventionally measured in the LFS, while the latter two states arise from separating the conventional "out-of-the-labor force" category O into two components, M and N. Although a variety of possible definitions of marginal attachment are examined, our primary focus is on individuals who did not search for work but report that they desired work. The "not attached" state (N) then consists of those individuals who neither searched for nor desired work.

Labor market dynamics are represented by a $4 \times 4$ transition matrix $\mathrm{P}$ where the $\mathrm{ij}$ element $\mathrm{p}_{\mathrm{ij}}$ is the probability of an individual being in state $\mathrm{j}$ in the next period given that the individual is in state $\mathrm{i}$ in the current period: 


$$
P=\left(\begin{array}{cccc}
p E E & p E U & p E M & p E N \\
p U E & p U U & p U M & p U N \\
p M E & p M U & p M M & p M N \\
p N E & p N U & p N M & p N N
\end{array}\right)
$$

In this Markov model context, necessary and sufficient conditions for "marginal attachment" and "not attached" to be behaviorally identical states are that the probability of transiting from $\mathrm{M}$ to $\mathrm{E}$ equals that of transiting from $\mathrm{N}$ to $\mathrm{E}$ and the probability of transiting from $\mathrm{M}$ to $\mathrm{U}$ equals that of transiting from $\mathrm{N}$ to $\mathrm{U}$. That is,

$$
\begin{aligned}
& p M E=p N E \\
& p M U=p N U
\end{aligned}
$$

In these circumstances the 4 state Markov model collapses to a three state model in which the conventional measures of labor force activity (E, $\mathrm{U}$ and $\mathrm{O}$ ) are appropriate. ${ }^{11}$ The desire for work conveys no additional information regarding labor force attachment beyond that provided by the activity of job search.

On the other hand, it may be the case that the conventional job search requirement for unemployment is too narrow, and that marginally attached workers are not behaviorally distinct from the unemployed; that is,

$$
\begin{aligned}
& p U E=p M E \\
& p U N=p M N
\end{aligned}
$$

In these circumstances, the measurement of unemployment should be based on the desire for work rather than on job search. The desire for workalone distinguishes between unemployment and non-participation: no additional information is conveyed by the activity of job search.

If both (2) and (3) were rejected, we might expect it to be the case that 


$$
\begin{aligned}
& p U E>p M E>p N E \\
& p U U>p M U>p N U \\
& p U N<p M N<p N N
\end{aligned}
$$

In these circumstances, a four state model is appropriate, and there may be a rationale for statistical agencies to report unemployment, marginal attachment and non-attachment on a regular basis.

Our empirical analysis consists of a series of tests of the restrictions (2) and (3). In addition we report tests for the behavioral equivalence of subsets of the marginal attachment category, such as those who did not search because they are "discouraged" or "waiting," and thus explore the possibility that various within-category distinctions might be empirically important.

An analogous framework can be used to analyze heterogeneity within the $\mathrm{U}$ category. ${ }^{12}$ For example, let A and $\mathrm{P}$ denote active and passive job searchers, respectively, so that the four states become $\mathrm{E}, \mathrm{A}, \mathrm{P}$ and $\mathrm{O}$. Then $\mathrm{A}$ and $\mathrm{P}$ will be equivalent iff $\mathrm{pAE}=\mathrm{pPE}$ and $\mathrm{pAO}=\mathrm{pPO}$, in which case the criteria used in many $\mathrm{OECD}$ countries would be supported. The equivalence of $\mathrm{P}$ and $\mathrm{O}$ is implied by the restrictions $\mathrm{pPE}=\mathrm{pOE}$ and $\mathrm{pPA}=\mathrm{pOA}$, in which case the US criteria would be supported.

\section{Data Collection And Construction}

Our data come from linking each individual in the SJO, an annual supplement to the LFS, to that individual in the subsequent month of the LFS. The advantage of the SJO is that it provides information on the desire for work among those who did not search for work as well as their reasons for not searching. The SJO has been administered each March since 1979 (except in March 1990) and in September of 1981 and 1984. Thus we have 15 longitudinal files covering the period 1979-1992. Each file consists of approximately 100,000 to 120,000 respondents to the LFS, of whom about 30,000 to 40,000 also respond to the SJO.

The creation of these longitudinal files utilizes the rotation group feature of the LFS. Respondents remain in the LFS for six consecutive months. Each month, approximately 1/6th of the sample exits from the survey and is replaced by an incoming rotation group. Thus 5/6ths of the sample is common to adjacent months. Our microdata 
files consist of all the available information on each individual in the LFS and, if applicable, the SJO in March (or September) of the survey year plus the labor force status (E, U or O) of the SJO respondents remaining in the LFS in April (or October). ${ }^{13}$ Note that this structure implies that we observe each individual in one of four states (E, U, M, $\mathrm{N}$ ) in March (or September) but in one of three states (E, U, O) in April (or October). Our empirical matrix of transitions from the non-employment states is hence given by:

$$
P_{S J O \rightarrow L F S}=\left(\begin{array}{ccc}
p U E & p U U & p U O \\
p M E & p M U & p M O \\
p N E & p N U & p N O
\end{array}\right)
$$

The fact that we do not observe all possible transitions among the states implied by the $4 \times 4$ framework of (1) means that there are some tests that we cannot carry out. Restriction (2), the equivalence of M and N, can be tested with these data while the first equality restriction of (3), the equivalence of $U$ and $M$, can also be tested. However, our inability to observe the $\mathrm{N}$ destination state restricts full testing of both elements of (3). ${ }^{14}$ Similarly, in the unemployment heterogeneity case, the restrictions $\mathrm{pAE}=\mathrm{pPE}, \mathrm{pAO}=\mathrm{pPO}$ and $\mathrm{pPE}=\mathrm{pOE}$ can be tested but $\mathrm{pPA}=\mathrm{pOA}$ cannot.

Excluded from the analysis are non-employed classified as permanently unable to work, on temporary layoff, and having a job to start at a definite date in the future. For the latter two groups, the distinction between $\mathrm{U}$ and $\mathrm{O}$ is based on availability for work rather than job search. ${ }^{15}$ Thus we focus on those with "no job attachment," for whom the question of whether unemployment should be based on job search or on a weaker requirement such as the desire for work is clearly most meaningful. This group accounts for 85 to 90 percent of the unemployed and over 90 percent of non-participants.

Assignment of marginal attachment is based on the response to the SJO question "Did ... want a job last week?" Individuals responding "Yes" to this question (who are classified by the LFS as O) are assigned to the M category; the remainder are treated as "not attached" $(\mathrm{N})$.

\section{EMPIRICAL RESULTS}

Table I reports transition rates averaged over recession and non-recession periods and Figure 1 plots several hazards into E. Several features are noteworthy. First, the transition rates display considerable stability over time. Apart from the sharp declines during the two recessions, the hazards into E move in a narrow range over the 1979-92 
period; transitions into $\mathrm{U}$ and $\mathrm{O}$ display similar temporal stability. Second, the rankings are the same in each period: $\mathrm{pUE}>\mathrm{pME}>\mathrm{pNE} ; \mathrm{pUU}>\mathrm{pMU}>\mathrm{pNU}$; and $\mathrm{pUO}<\mathrm{pMO}<\mathrm{pNO}$. Furthermore, the difference between $\mathrm{pME}$ and $\mathrm{pNE}$ is consistently much greater than the difference between pUE and pME. These unconditional data thus suggest that the behavior of the "marginal attachment" group is closer to that of the unemployed than to the "not attached," but that unemployment and marginal attachment may nonetheless be distinct labor force states. The fact that pME is close to pUE indicates that the desire for work among non-searchers conveys considerable information about labor force attachment.

Table I also reports hazards into E for sub-groups of the marginal attachment category according to reasons given for not searching. The "Waiting" category corresponds to those not searching because of "waiting for recall (to former job)," "has found new job," or "waiting for replies from employers," while "discouraged" refers to those not searching because “... believes no work available (in area, or suited to skills)." For individuals in the Waiting category, the probability of obtaining employment substantially exceeds not only that of the other sub-categories, but also that of the unemployed. The transition probabilities of the Non-Waiting groups (Personal, Discouraged, Other) are generally similar to each other in magnitude. Because of these differences within the marginally attached, Figure 1 plots separate hazards for the Waiting $[\mathrm{M}(\mathrm{W})]$ and Non-Waiting $[\mathrm{M}(\mathrm{NW})]$ components. Based on the likelihood of becoming employed, the Non-Waiting group exhibits labor force attachment in between that of the unemployed and the not attached. In contrast, the Waiting category exhibits stronger attachment than those classified as U, suggesting that in some circumstances waiting may be as productive as search in terms of obtaining employment. ${ }^{16}$ The fact that $\mathrm{pM}(\mathrm{W}) \mathrm{E}>\mathrm{pUE}$ may also indicate that the criteria for "temporary layoffs" and "future job starts" may be too stringent. ${ }^{17}$

These results indicate that the $\mathrm{O}$ category is very heterogeneous; in particular, non-searchers who desire work exhibit behavior markedly different from those who do not desire work. Analogously, Table II examines the extent of heterogeneity within the unemployed. ${ }^{18}$ The top part of the table reports hazards into E by job search method for all searchers, many of whom employ more than one method. The four categories are those available on the public use files. These average transition rates are quite stable during "normal" periods, decline sharply during recessions, and do not differ systematically by search method. Also shown in Table II are hazards into E for those using only one search method, using multiple methods, and using active methods. ${ }^{19}$ Those whose sole method is "used public 
employment agency" or "looked at ads" are relatively unsuccessful in obtaining employment. Whether the latter finding supports the US protocol of excluding passive searchers from the unemployed is tested subsequently.

The bottom part of Table II shows transition rates into E broken down by reason for becoming unemployed. Two groups within the unemployed stand out as having poor (short term) employment prospects: new entrants and reentrants out of the labor force more than one year. The finding that re-entrants who have been out of the labor force less than one year have employment probabilities very similar to those losing or leaving jobs provides some support for the view that brief periods of labor force withdrawal may be very similar to periods of unemployment.

We next investigate the extent to which the results apparent in the unadjusted figures for the various transition rates are maintained once we condition on observables. Notice that, for the question of whether the current measure of unemployment is an appropriate one, the unconditional figures—which reflect the transition rates of the particular sample in each sub-group - may be correct. However, for the broader question of whether the current measures are appropriate no matter what the characteristics of individuals in each sub-group, a conditional analysis is called for.

For each of the 15 linked SJO-LFS samples we estimate multinomial logit models to test $\mathrm{M}=\mathrm{N}$ (and the equivalence of $\mathrm{N}$ with various subsets of $\mathrm{M}$ ) and binary logit models to test $\mathrm{U}=\mathrm{M}, \mathrm{U}=\mathrm{N}$, and the equivalence of $\mathrm{U}$ with $\mathrm{M}(\mathrm{W})$ and $\mathrm{M}(\mathrm{NW})$. For 13 of these datasets, we are also able to test for heterogeneity within the unemployed group, using binary logit tests for $\mathrm{P}=\mathrm{O}$ and a multinomial model for $\mathrm{A}=\mathrm{P} .{ }^{20}$ All estimated equations control for gender, marital status, education, age and region. ${ }^{21}$ Each test consists of three estimated equations, one for each of the two distinct origin states and one for the pooled origin state; the latter imposes the restriction that all coefficients are equal across the two origin states into each destination state. The estimates themselves are too numerous to report here; rather we provide in Table III the p-values associated with each of the likelihood ratio tests. ${ }^{22}$

The null hypothesis of equivalence of Marginal and Not Attached origin states is decisively rejected in each sample. In order to check that this result is not affected by the maintained assumptions of the multinomial logit model, we also carried out separate binary logit tests of each restriction ( $\mathrm{pME}=\mathrm{pNE}$ and $\mathrm{pMU}=\mathrm{pNU}$ ); these are also decisively rejected in all samples. The binary logit tests also strongly reject pUE=pNE, which is necessary for the equivalence of $\mathrm{U}$ and $\mathrm{N}$. Thus, as is expected from the unconditional transition probabilities in Table I, the equivalence of both 
$\mathrm{U}$ and $\mathrm{N}$ and that of $\mathrm{M}$ and $\mathrm{N}$ is clearly rejected by our data. Both job search and the desire for work convey substantial information about labor force attachment.

Based on binary logit tests of pUE=pME, the equivalence of $\mathrm{U}$ and $\mathrm{M}$ is rejected in a majority of years. However, in years such as 1982, 1984, and 1992 (see also Figure 1), the equality of these hazards cannot be rejected. More definitive results are obtained when separate tests are carried out for the Waiting and Non-Waiting subsets of M. The equivalence of $U$ and $M(N W)$ is rejected in all cases, as is the equivalence of $M(N W)$ and $N$. Thus the desire for work conveys important information about labor force activity, but job search conveys additional information. The tests also reject $\mathrm{U}=\mathrm{M}(\mathrm{W})$ at the $1 \%$ level in all but one sample; however, this rejection occurs because $\mathrm{pM}(\mathrm{W}) \mathrm{E}>\mathrm{pUE}$ rather than the reverse (as is the case for the $\mathrm{pM}(\mathrm{NW}) \mathrm{E}$ hazard). Accordingly, $\mathrm{M}(\mathrm{W})=\mathrm{N}$ is decisively rejected. Thus the Waiting subgroup within M appears mis-classified as non-participants, and would be more appropriately included among the unemployed. Also, our results reject the equivalence of $U$ and $M(D)$, the discouraged worker subset of the Marginal group, and also reject the equivalence of $\mathrm{M}(\mathrm{D})$ and $\mathrm{N}$, the latter using a multinomial test. In terms of both transition rates and test statistics, the $M(D)$ group appear quite similar to the remainder of the $M(N W)$ subset.

The binary logit tests also decisively reject $\mathrm{P}=\mathrm{O}$, as is expected from the large differences between the hazards into $\mathrm{E}$ from passive search (Table II) and from $\mathrm{O}^{23}$ At the same time, passive and active search do appear to be behaviorally different activities; $\mathrm{A}=\mathrm{P}$ is rejected in all years for which the test can be conducted, reflecting the differences between $\mathrm{pAE}$ and $\mathrm{pPE}$ and between $\mathrm{pAO}$ and $\mathrm{pPO}$. These results suggest that, while there may be a case for treating passive and active search differently, the inclusion of passive searchers as non-participants—as is currently done in the US and some other countries-is strongly rejected by our data.

\section{CONCLUSIONS}

The primary objective of this paper is to examine the validity of current methods for distinguishing between unemployment and out-of-the-labor force. In particular we examine whether those who desire but are not seeking work (the marginally attached) display behavior distinct from both those seeking work (the unemployed as conventionally measured) and those who report that they neither desire nor are seeking work (the unattached). This analysis requires longitudinal data in which three non-employment states (U, M and N) are observed. For this purpose we utilize 15 longitudinal data sets created by linking the SJO (which provides a detailed breakdown of non-employment according 
to various degrees of labor force attachment) and the LFS in the subsequent month, which gives information on subsequent labor market events.

One principal finding is that marginal attachment and non-attachment are distinct labor force states, as are unemployment and non-attachment. Likelihood ratio tests clearly reject equality of $\mathrm{M}$ and $\mathrm{N}$ and of $\mathrm{U}$ and $\mathrm{N}$ at the $1 \%$ level in all 15 samples. These results indicate that "non-participation" is a behaviorally meaningful designation, but also that there is an important degree of heterogeneity among the group conventionally classified as not-in-the-labor force: those who indicate that they desire work exhibit distinctly different behavior from the remainder of this group. The desire for work among non-searchers reflects more than "dreaming"; indeed, it conveys considerable information about labor force attachment and future employment status.

Our second principal finding is that the "Waiting" sub-category of marginal attachment—those who desire but are not seeking work because of "waiting for recall," "has found new job" or "waiting for replies from employers"- display behavior closer to the unemployed than to the rest of the marginal attachment group and to the non attached. Indeed, the average transition rate into employment for this "Waiting" group is higher than for those classified as unemployed. While equivalence of $\mathrm{M}(\mathrm{W})$ and $\mathrm{U}$ is rejected in all years but 1979 , the rejections arise because those in the Waiting subcategory of M display a stronger attachment to the labor force than the unemployed. Waiting is recognized by current measurement procedures as a form of unemployment in some cases, as is evident from the special provisions for "future job starts" and "temporary layoffs;" however, our results indicate that the importance of waiting as a form of unemployment is not sufficiently recognized by these provisions. This result provides some support for theoretical models which emphasize wait unemployment, and suggests that current (Canadian) definitions of temporary layoffs and future job starts may be too stringent. More generally, our results suggest that those in the "Waiting" category should be classified as unemployed rather than out-of-the-labor force. ${ }^{24}$

A third conclusion is that once wait unemployment is removed from the marginal attachment category, the equivalence of $\mathrm{U}$ and $\mathrm{M}(\mathrm{NW})$ is rejected, as is that of $\mathrm{M}(\mathrm{NW})$ and $\mathrm{N}$. Those who desire but are not searching for work appear to be an intermediate category whose behavior lies between that of the unemployed and other non-participants. This finding suggests that for many purposes it would be useful for statistical agencies to report four labor force states and for econometric analyses of labor market transitions to be carried out in a multi-state model of non-employment. 
The paper also investigates heterogeneity within those engaged in job search, in part motivated by differences across countries in search methods used to distinguish unemployment from non-participation. We do find that those who use only "looked at ads" or "used public employment agencies" have significantly lower probabilities of obtaining employment than those using other search methods or multiple methods. However, this finding does not support the position that those using only passive methods should be classified as non-participants. In particular, although these individuals have lower hazards into employment than those using other search methods, they also have significantly higher probabilities of obtaining employment (and significantly lower probabilities of labor force withdrawal) than nonsearchers. Our results provide some support for distinguishing between passive and active job seekers but no support for treating passive searchers as non-participants.

Taken as a whole, our results indicate that there is substantial heterogeneity within the non-employed. Thus any attempt to dichotomize the non-employed into "unemployment" and "out-of-the-labor force" is unlikely to fully capture the complexity of labor force activity. Nonetheless, job search and the desire for work are important indicators. Together these two activities allow the underlying distribution of degrees of labor force attachment to be separated into distinct groups that display different behavior. However, additional information appears necessary to identify activities such as "wait unemployment."

Dept. of Economics, McMaster University, Hamilton, Ontario, L8S 4M4, Canada; sj@jsbach.economics.mcmaster.ca; http://jsbach.economics.mcmaster.ca/sj.html

and

Dept. of Economics, University of British Columbia, Vancouver, B.C., V6T 1Z1, Canada; riddell@econ.ubc.ca 


\section{REFERENCES}

ABOwD, J., AND A. ZeLLnER (1985): “Estimating Gross Labor Force Flows," Journal of Business and Economic Statistics, 3, 254-83.

BLANChARD, O.J., AND P. DiAmOND (1992): “The Flow Approach to Labor Markets,” American Economic Review (Papers \& Proceedings), 82, 354-9.

BLAU, D.M., AND P.K. RoBINS (1986): “Labor Supply Response to Welfare Programs: A Dynamic Analysis,” Journal of Labor Economics, 4, 82-104.

BORTNICK, S.M., AND M.H. PORTS (1992): "Job Search Methods and Results: Tracking the Unemployed, 1991," Monthly Labor Review, 115, 29-35.

BULOW, J.L., AND L.H. SuMmerS (1986): “A Theory of Dual Labor Markets with Application to Industrial Policy, Discrimination, and Keynesian Unemployment," Journal of Labor Economics, 4, 376-414.

Burdett, K., N. Kiefer, D. Mortensen, AND G. NeumanN (1984): "Earnings, Unemployment, and the Allocation of Time over Time," Review of Economic Studies, 51, 559-78.

CARD, D., AND W.C. RIDDELL (1993): “A Comparative Analysis of Unemployment in Canada and the United States,” in Small Differences That Matter: Labor Markets and Income Maintenance in Canada and the United States, ed. by D. Card and R.B. Freeman. Chicago: University of Chicago Press and NBER, 149-89.

ClARK, K., AND L.H. SUMMERS (1979): “Labor Market Dynamics and Unemployment: A Reconsideration,” Brookings Papers on Economic Activity, 1979:1, 13-60.

FLINN, C.J., AND J.J. HECKMAN (1983): “Are Unemployment and Out of the Labor Force Behaviorally Distinct Labor Force States?" Journal of Labor Economics, 1, 28-42.

GöNÜL, F. (1992): "New Evidence on Whether Unemployment and Out of the Labor Force are Distinct States," Journal of Human Resources, 27, 329-61.

HALL, R.E. (1970): “Why Is the Unemployment Rate So High at Full Employment?” Brookings Papers on Economic Activity, 1970:3, 369-402. 
(1975): “The Rigidity of Wages and the Persistence of Unemployment," Brookings Papers on Economic Activity, 1975:2, 301-35.

(1983): “Is Unemployment a Macroeconomic Problem?” American Economic Review (Papers \& Proceedings), 73, 219-22.

HAUSMAN, J.A. AND F.M. SCOTT MORTON, 1994, “Misclassification of a Dependent Variable in a Discrete Response Setting," MIT Department of Economics Working Paper 94-19.

JONES, S.R.G. (1987): “Screening Unemployment in a Dual Labor Market,” Economics Letters, 25, 191-5.

JONES, S.R.G., AND W.C. RIDDELL (1995): “The Measurement of Labor Force Dynamics with Longitudinal Data: The Labour Market Activity Survey Filter,” Journal of Labor Economics, 13, 351-85.

Juhn, C., K.M. MurPhy, AND R.H. TOPEL (1991): "Why Has the Natural Rate of Unemployment Increased Over Time?" Brookings Papers on Economic Activity, 1991:2, 75-126.

LUCAS, R.E. JR., AND L.A. RAPPING (1969): “Real Wages, Employment and Inflation,” Journal of Political Economy, $77,721-54$

MCDONALD, I.M., AND R.M. Solow (1985): "Wages and Employment in a Segmented Labor Market," Quarterly Journal of Economics, 100, 1115-41.

NATIONAL COMMISSION ON EMPLOYMENT AND UNEMPLOYMENT STATISTICS (1979): Counting the Labor Force. Washington: USGPO.

NiCKELl, S., AND B. BELl (1995): "The Collapse in Demand for the Unskilled and Unemployment Across the OECD," Oxford Review of Economic Policy, 11, 40-62.

NoRwOOD, J.L. (1988): “The Measurement of Unemployment” American Economic Review (Papers \& Proceedings), $78,284-8$.

ORGANIZATION FOR ECONOMIC COOPERATION AND DEVElOPMENT (1987): “On the Margin of the Labour Force: An Analysis of Discouraged Workers and other Non-Participants," Employment Outlook, September, 142-70.

------- (1995): “Supplementary Measures of Labour Market Slack,” Employment Outlook, July, 43-97.

OsBerG, L. (1993): "Fishing in Different Pools: Job Search Strategies and Job-finding Success in the Early 1980s," Journal of Labor Economics, 11, 348-86. 
POTERBA, J.M., AND L.H. SUMMERS (1986): “Reporting Errors and Labor Market Dynamics,” Econometrica, 54, 131938. (1995): “Unemployment Benefits and Labor Market Transitions," Review of Economics and Statistics, 77, 207-

16.

PREsident's COMmitTeE to APPRAISE EMPloyment AND UnEMPloyment Statistics (1962): Measuring Employment and Unemployment. Washington: USGPO.

STEIN, R.L. (1967): “New Definitions for Employment and Unemployment,” Employment and Earnings, 13, 3-27.

TANO, D.K. (1991): “Are Unemployment and Out of the Labor Force Behaviorally Distinct Labor Force States?" Economics Letters, 36, 113-7.

VAN DEN BERG, G.J. (1990): "Search Behaviour, Transitions to Nonparticipation and the Duration of Unemployment," Economic Journal, 100, 842-65.

ZAGORSKY, J.L. (1996): “The Effect of Definitional Differences on US and Canadian Unemployment Rates," Canadian Business Economics, 4,13-21. 


\section{NOTES}

1. We are grateful to Garry Barrett, Alan Stark and Arthur Sweetman for excellent research assistance, to the SSHRC and CILN for research support, and to Ian Macredie, Scott Murray and Ray Ryan of Statistics Canada for their assistance in providing access to the data used in this study. Earlier versions of this paper were presented at the Canadian Economics Association meetings, Canadian Labour Economics Conference, European Association of Labour Economists and at the Australian Bureau of Statistics, Australian National University, CIRANO, CREST, Curtin University, DELTA, European University Institute, Reserve Bank of Australia, Université du Québec à Montréal and the Universities of British Columbia, New South Wales, Newcastle, Sydney, and Western Australia. We thank participants in these seminars and Denise Doiron, Martin Dooley, David Green, John Kennan, Thomas Lemieux, John Micklewright and Chris Ragan for comments. We are also grateful to the referees and co-editor David Card for their useful suggestions.

2. As stated by the President's Committee to Appraise Employment and Unemployment Statistics (1962, p.49):

"When should a person not working but wanting work be included in the labor force and thus counted as unemployed? This constitutes the most difficult question with which the Committee has had to deal." For subsequent discussion of these issues see National Commission on Employment and Unemployment Statistics (1979), Norwood (1988) and OECD (1987, 1995).

3. The principal exceptions to the job search requirement are for persons on temporary layoff awaiting recall to a former job and persons who have a job to start in the near future. For these two groups, availability for work rather than job search is the criterion used to distinguish between $\mathrm{U}$ and $\mathrm{O}$.

4. An example is the phenomenon of "rotation group bias" whereby measured unemployment and participation differ systematically across survey rotation groups, each of which is a representative sample of the population (Hall, 1970; Clark and Summers, 1979).

5. Studies that have employed a three-state model of labor market behavior include Burdett, Kiefer, Mortensen and Neumann (1984), Blau and Robins (1986) and van den Berg (1990).

6. In many countries, measurement procedures do attempt to capture two forms of waiting-individuals on temporary layoff and with jobs to start in the near future (see footnote 3)—but other forms such as waiting for 
replies to job applications or simply waiting for jobs to open up are not captured.

7. In this context, it is worth noting that several recent studies of "unemployment" also investigate non-

employment (Juhn, Murphy and Topel, 1991; Card and Riddell, 1993; Nickell and Bell, 1995), suggesting that an analysis of $\mathrm{U}$ alone may be too confining.

8. The NLSY work is also handicapped by the problem that only the duration of the non-employment spell and the fraction of the spell spent searching for work are observed. Flinn and Heckman deal with this problem by excluding all non-employment spells which are partially spent unemployed. This procedure, however, involves considerable loss of data and raises questions about the generalizability of the results. Gönül does not delete observations, which necessitates allowing for all possible cases in a combinatorial fashion and which requires some maintained assumptions such as stationarity.

9. Canada's Labour Market Activity Survey identifies non-searchers who desire work but the questionnaire structure filters the data in a way that makes them unsuitable for the analysis carried out here (Jones and Riddell, 1995). Other available longitudinal data sets are limited to the states E, U and O.

10. Prior to 1994, questions about the desire for work in the US CPS were asked only of members of the two outgoing rotation groups, so that the type of longitudinal matching we shall undertake for these Canadian data was not possible using the CPS.

11. Note that there is no necessary equivalent condition for the transition rates into the two potentially equivalent states. Flinn and Heckman (1983, p.32) advance a "proportionality" condition, however.

12. Other research which has investigated the consequences of alternative search methods includes Bortnick and Ports (1992) and Osberg (1993).

13. The fact that individuals in the origin month are observed to have answered the SJO with its detailed questions about desire for a job and reasons for non-search may reduce the degree of measurement error for that month, although the usual gross flow classification error problems will affect the destination month for which we only observe the LFS. For related work with similar classification measurement error, see Hausman and Scott-Morton (1994) and Poterba and Summers (1995).

14. Note that, while the SJO state N (not attached) is not observed as a destination state in the LFS, a rejection of $\mathrm{pUE}=\mathrm{pME}$ is sufficient to reject equivalence of the two states. The one case our present data cannot address is 
where $\mathrm{U}$ and $\mathrm{M}$ are not equivalent because $\mathrm{pUN}$ is distinct from $\mathrm{pMN}$, even though $\mathrm{pUE}=\mathrm{pME}$ cannot be rejected. 15. The LFS further distinguishes between short term and long term future job starts (FJS) according to whether the new job start is 1-4 or more than 4 weeks away. The distinction between $\mathrm{U}$ and $\mathrm{O}$ is based on availability for work for short term FJS, and on job search for long term FJS.

16. Although not shown in the table, the Waiting sub-group is also much less likely to withdraw from the labor force than are the Non-Waiting components.

17. In particular, those who give as their reason for not searching "waiting for recall (to former job)" or "has found new job" are not classified as temporary layoffs or future job starts respectively yet are evidently very likely to be employed in the following month. If these individuals were classified as temporary layoffs or (short term) future job starts, the distinction between $\mathrm{U}$ and $\mathrm{O}$ would be based on availability for work rather than job search. Two aspects of the current protocol may be excessively rigid. First, individuals expecting to be recalled to a seasonal job are not considered to be on temporary layoff. Second, to be classified as a future job start, individuals must have a job to start at a definite date in the future.

18. Because of the coding of the pre-1981 data, results are not available for the 1979:03 and the 1980:03 datasets. This omission is reflected in both Table II and the relevant test statistics in Table III.

19. An important qualification is that the "looked at ads" category on the public use LFS files includes both those who looked at ads and those who placed or answered ads. Since the latter is an active method it is not possible to separate active and passive searchers precisely with these data.

20. As noted above, we cannot carry out a precise test of $\mathrm{A}=\mathrm{P}$ and $\mathrm{P}=\mathrm{O}$ because those categorized as "looked at ads" in our data includes those who looked at ads (passive search) and those who placed or answered ads (active search).

21. Exclusive of the omitted categories, the estimated models have four regions and one dummy variable each for sex, currently married, age (25 years and older) and education (some "post-secondary" or higher).

22. The full binary and multinomial logit estimates are available on request.

23. The hazards from $\mathrm{O}$ naturally lie between those from $\mathrm{M}$ and from $\mathrm{N}$ that are reported in Table I. For example, the 1992 figure for the mean of pOE is 0.034 . 
24. We have calculated "unemployment rates" for the March observations over the period 1979-91 both excluding and including the $\mathrm{M}(\mathrm{W})$ group. The difference between the two series ranges from 0.8 to 1.2 and averages 1.0 percentage points. 
TABLE I

AVERAGE TRANSITION RATES IN RECESSION AND NON-RECESSION YEARS

\begin{tabular}{|c|c|c|c|c|}
\hline & \multicolumn{4}{|c|}{ Time Period } \\
\hline & $1979-81$ & $1982-83$ & 1984-91 & 1992 \\
\hline \multicolumn{5}{|c|}{ Transitions into employment: } \\
\hline pUE & $\begin{array}{l}.180 \\
(.006)\end{array}$ & $\begin{array}{l}.115 \\
(.004)\end{array}$ & $\begin{array}{l}.157 \\
(.005)\end{array}$ & $\begin{array}{l}.112 \\
(.004)\end{array}$ \\
\hline pME & $\begin{array}{l}.124 \\
(.007)\end{array}$ & $\begin{array}{l}.085 \\
(.005)\end{array}$ & $\begin{array}{l}.123 \\
(.007)\end{array}$ & $\begin{array}{l}.098 \\
(.005)\end{array}$ \\
\hline $\mathrm{pNE}$ & $\begin{array}{l}.030 \\
(.001)\end{array}$ & $\begin{array}{l}.023 \\
(.001)\end{array}$ & $\begin{array}{l}.028 \\
(.001)\end{array}$ & $\begin{array}{l}.026 \\
(.001)\end{array}$ \\
\hline \multicolumn{5}{|c|}{$\begin{array}{l}\text { Transitions from marginal attachment } \\
\text { sub-categories into employment: }\end{array}$} \\
\hline $\begin{array}{l}\mathrm{pM}(\mathrm{W}) \mathrm{E} \\
\text { Waiting }\end{array}$ & $\begin{array}{l}.230 \\
(.016)\end{array}$ & $\begin{array}{l}.165 \\
(.012)\end{array}$ & $\begin{array}{l}.235 \\
(.015)\end{array}$ & $\begin{array}{l}.200 \\
(.012)\end{array}$ \\
\hline $\begin{array}{l}\mathrm{pM}(\mathrm{NW}) \mathrm{E} \\
\text { Non-Waiting }\end{array}$ & $\begin{array}{l}.083 \\
(.007)\end{array}$ & $\begin{array}{l}.053 \\
(.005)\end{array}$ & $\begin{array}{l}.071 \\
(.006)\end{array}$ & $\begin{array}{l}.052 \\
(.005)\end{array}$ \\
\hline $\begin{array}{l}\mathrm{pM}(\mathrm{P}) \mathrm{E} \\
\text { Personal }\end{array}$ & $\begin{array}{l}.076 \\
(.011)\end{array}$ & $\begin{array}{l}.056 \\
(.009)\end{array}$ & $\begin{array}{l}.075 \\
(.010)\end{array}$ & $\begin{array}{l}.037 \\
(.006)\end{array}$ \\
\hline $\begin{array}{l}\mathrm{pM}(\mathrm{D}) \mathrm{E} \\
\text { Discouraged }\end{array}$ & $\begin{array}{l}.075 \\
(.010)\end{array}$ & $\begin{array}{l}.046 \\
(.006)\end{array}$ & $\begin{array}{l}.057 \\
(.009)\end{array}$ & $\begin{array}{l}.044 \\
(.007)\end{array}$ \\
\hline $\begin{array}{l}\mathrm{pM}(\mathrm{O}) \mathrm{E} \\
\text { Other }\end{array}$ & $\begin{array}{l}.114 \\
(.017)\end{array}$ & $\begin{array}{l}.072 \\
(.014)\end{array}$ & $\begin{array}{c}.098 \\
(.019)\end{array}$ & $\begin{array}{l}.112 \\
(.018)\end{array}$ \\
\hline \multicolumn{5}{|c|}{ Transitions into unemployment: } \\
\hline pUU & $\begin{array}{c}.614 \\
(.008)\end{array}$ & $\begin{array}{c}.711 \\
(.006)\end{array}$ & $\begin{array}{c}.670 \\
(.006)\end{array}$ & $\begin{array}{l}.708 \\
(.005)\end{array}$ \\
\hline pMU & $\begin{array}{c}.215 \\
(.009)\end{array}$ & $\begin{array}{l}.212 \\
(.007)\end{array}$ & $\begin{array}{c}.203 \\
(.008)\end{array}$ & $\begin{array}{l}.171 \\
(.007)\end{array}$ \\
\hline $\mathrm{pNU}$ & $\begin{array}{c}.018 \\
(.001)\end{array}$ & $\begin{array}{l}.019 \\
(.001)\end{array}$ & $\begin{array}{c}.022 \\
(.001)\end{array}$ & $\begin{array}{c}.030 \\
(.001)\end{array}$ \\
\hline \multicolumn{5}{|c|}{ Transitions into out-of-the-labor force: } \\
\hline pUO & $\begin{array}{c}.207 \\
(.006)\end{array}$ & $\begin{array}{l}.174 \\
(.005)\end{array}$ & $\begin{array}{l}.172 \\
(.005)\end{array}$ & $\begin{array}{l}.180 \\
(.005)\end{array}$ \\
\hline pMO & $\begin{array}{l}.661 \\
(.010)\end{array}$ & $\begin{array}{c}.704 \\
(.008)\end{array}$ & $\begin{array}{c}.674 \\
(.010)\end{array}$ & $\begin{array}{c}.731 \\
(.008)\end{array}$ \\
\hline $\mathrm{pNO}$ & $\begin{array}{c}.953 \\
(.001)\end{array}$ & $\begin{array}{c}.959 \\
(.001)\end{array}$ & $\begin{array}{c}.950 \\
(.001)\end{array}$ & $\begin{array}{c}.944 \\
(.002)\end{array}$ \\
\hline
\end{tabular}

${ }^{\text {a }}$ Standard errors in parentheses. 
TABLE II

TRANSITION RATES by SEARCh METHOD AND REASON FOR UNEMPLOYMENT,

RECESSION AND NON-RECESSION YEARS

\begin{tabular}{|c|c|c|c|c|}
\hline & \multicolumn{4}{|c|}{ Time Period } \\
\hline & 1981 & $1982-83$ & 1984-91 & 1992 \\
\hline \multicolumn{5}{|l|}{ Transitions into E: } \\
\hline \multicolumn{5}{|c|}{ BY Job search method (one or more methods used): } \\
\hline Contacted employers & $\begin{array}{l}.190 \\
(.007)\end{array}$ & $\begin{array}{l}.118 \\
(.005)\end{array}$ & $\begin{array}{l}.167 \\
(.006)\end{array}$ & $\begin{array}{l}.118 \\
(.005)\end{array}$ \\
\hline $\begin{array}{l}\text { Used public employment } \\
\text { agency }\end{array}$ & $\begin{array}{l}.167 \\
(.008)\end{array}$ & $\begin{array}{l}.115 \\
(.006)\end{array}$ & $\begin{array}{l}.156 \\
(.007)\end{array}$ & $\begin{array}{l}.109 \\
(.006)\end{array}$ \\
\hline Looked at ads & $\begin{array}{l}.188 \\
(.010)\end{array}$ & $\begin{array}{l}.112 \\
(.006)\end{array}$ & $\begin{array}{l}.154 \\
(.007)\end{array}$ & $\begin{array}{l}.111 \\
(.005)\end{array}$ \\
\hline Other & $\begin{array}{l}.219 \\
(.017)\end{array}$ & $\begin{array}{l}.131 \\
(.010)\end{array}$ & $\begin{array}{l}.173 \\
(.011)\end{array}$ & $\begin{array}{l}.110 \\
(.008)\end{array}$ \\
\hline Used multiple methods & $\begin{array}{l}.190 \\
(.008)\end{array}$ & $\begin{array}{l}.115 \\
(.005)\end{array}$ & $\begin{array}{l}.162 \\
(.006)\end{array}$ & $\begin{array}{l}.113 \\
(.005)\end{array}$ \\
\hline Used "active methods" & $\begin{array}{l}.181 \\
(.006)\end{array}$ & $\begin{array}{l}.116 \\
(.004)\end{array}$ & $\begin{array}{l}.162 \\
(.005)\end{array}$ & $\begin{array}{l}.115 \\
(.004)\end{array}$ \\
\hline \multicolumn{5}{|c|}{ BY Job search method (single method used): } \\
\hline Contacted employers & $\begin{array}{l}.179 \\
(.012)\end{array}$ & $\begin{array}{l}.124 \\
(.009)\end{array}$ & $\begin{array}{l}.168 \\
(.010)\end{array}$ & $\begin{array}{l}.124 \\
(.008)\end{array}$ \\
\hline $\begin{array}{l}\text { Used public employment } \\
\text { agency }\end{array}$ & $\begin{array}{l}.095 \\
(.014)\end{array}$ & $\begin{array}{c}.082 \\
(.010)\end{array}$ & $\begin{array}{l}.121 \\
(.015)\end{array}$ & $\begin{array}{l}.089 \\
(.014)\end{array}$ \\
\hline Looked at ads & $\begin{array}{l}.129 \\
(.021)\end{array}$ & $\begin{array}{l}.103 \\
(.016)\end{array}$ & $\begin{array}{l}.108 \\
(.015)\end{array}$ & $\begin{array}{l}.085 \\
(.011)\end{array}$ \\
\hline Other & $\begin{array}{l}.262 \\
(.040)\end{array}$ & $\begin{array}{l}.169 \\
(.027)\end{array}$ & $\begin{array}{l}.220 \\
(.034)\end{array}$ & $\begin{array}{l}.130 \\
(.024)\end{array}$ \\
\hline \multicolumn{5}{|c|}{ BY Reason for Flow into Unemployment: } \\
\hline Job losers & $\begin{array}{l}.183 \\
(.009)\end{array}$ & $\begin{array}{l}.128 \\
(.006)\end{array}$ & $\begin{array}{l}.176 \\
(.007)\end{array}$ & $\begin{array}{l}.123 \\
(.005)\end{array}$ \\
\hline New entrants & $\begin{array}{l}.119 \\
(.021)\end{array}$ & $\begin{array}{l}.062 \\
(.015)\end{array}$ & $\begin{array}{l}.099 \\
(.020)\end{array}$ & $\begin{array}{l}.048 \\
(.015)\end{array}$ \\
\hline Re-entrants (<1 year) & $\begin{array}{l}.218 \\
(.016)\end{array}$ & $\begin{array}{l}.113 \\
(.011)\end{array}$ & $\begin{array}{l}.168 \\
(.014)\end{array}$ & $\begin{array}{l}.127 \\
(.011)\end{array}$ \\
\hline Re-entrants (> 1 year) & $\begin{array}{c}.098 \\
(.013)\end{array}$ & $\begin{array}{c}.074 \\
(.011)\end{array}$ & $\begin{array}{c}.091 \\
(.011)\end{array}$ & $\begin{array}{c}.059 \\
(.009)\end{array}$ \\
\hline \multicolumn{5}{|l|}{ Transitions into O: } \\
\hline \multicolumn{5}{|c|}{ BY Search method(s) used: } \\
\hline Looked at ads & $\begin{array}{c}.323 \\
(.030)\end{array}$ & $\begin{array}{c}.252 \\
(.022)\end{array}$ & $\begin{array}{c}.260 \\
(.021)\end{array}$ & $\begin{array}{c}.234 \\
(.017)\end{array}$ \\
\hline Used "active" method(s) & $\begin{array}{l}.199 \\
(.007)\end{array}$ & $\begin{array}{l}.169 \\
(.005)\end{array}$ & $\begin{array}{l}.164 \\
(.005)\end{array}$ & $\begin{array}{c}.174 \\
(.005)\end{array}$ \\
\hline
\end{tabular}

${ }^{\text {a }}$ Standard errors in parentheses.

b "Active" search consists of all methods except individuals using only "looked at ads." 
TABLE III

Probability VALUES For LiKeliHOOd RATIO TESTS OF EQUIVALENCE

\begin{tabular}{|c|c|c|c|c|c|c|}
\hline \multirow[b]{2}{*}{ Sample } & \multicolumn{4}{|c|}{ Binary logit tests } & \multicolumn{2}{|c|}{ Multinomial logit test } \\
\hline & $\mathrm{U}=\mathrm{M}$ & $\mathrm{U}=\mathrm{M}(\mathrm{W})$ & $\begin{array}{c}\mathrm{U}=\mathrm{N} \\
\mathrm{U}=\mathrm{M}(\mathrm{NW}) \\
\mathrm{U}=\mathrm{M}(\mathrm{D})\end{array}$ & $\mathrm{P}=\mathrm{O}$ & $\begin{array}{c}\mathrm{M}=\mathrm{N} \\
\mathrm{M}(\mathrm{W})=\mathrm{N} \\
\mathrm{M}(\mathrm{NW})=\mathrm{N} \\
\mathrm{M}(\mathrm{D})=\mathrm{N}^{\mathrm{b}}\end{array}$ & $\mathrm{A}=\mathrm{P}$ \\
\hline 1979:03 & 0.00 & 0.04 & 0.00 & & 0.00 & \\
\hline 1980:03 & 0.00 & 0.00 & 0.00 & & 0.00 & \\
\hline 1981:03 & 0.00 & 0.01 & 0.00 & 0.00 & 0.00 & 0.00 \\
\hline 1981:09 & 0.00 & 0.01 & 0.00 & 0.00 & 0.00 & 0.00 \\
\hline $1982: 03$ & 0.25 & 0.00 & 0.00 & 0.00 & 0.00 & 0.00 \\
\hline 1983:03 & 0.01 & 0.00 & 0.00 & 0.00 & 0.00 & 0.00 \\
\hline 1984:03 & 0.24 & 0.00 & 0.00 & 0.00 & 0.00 & 0.00 \\
\hline 1984:09 & 0.00 & 0.00 & 0.00 & 0.00 & 0.00 & 0.00 \\
\hline 1985:03 & 0.00 & 0.00 & 0.00 & 0.00 & 0.00 & 0.00 \\
\hline 1986:03 & 0.00 & 0.00 & 0.00 & 0.00 & 0.00 & 0.00 \\
\hline $1987: 03$ & 0.06 & 0.00 & 0.00 & 0.00 & 0.00 & 0.00 \\
\hline 1988:03 & 0.01 & 0.00 & 0.00 & 0.00 & 0.00 & 0.00 \\
\hline 1989:03 & 0.00 & 0.00 & 0.00 & 0.00 & 0.00 & 0.00 \\
\hline 1991:03 & 0.01 & 0.00 & 0.00 & 0.00 & 0.00 & 0.00 \\
\hline 1992:03 & 0.51 & 0.00 & 0.00 & 0.00 & 0.00 & 0.00 \\
\hline
\end{tabular}

${ }^{a}$ The first four columns of p-values are results from binary logit tests of equivalence. For brevity, the third column reports the p-values for each of the binary tests listed, all of which are 0.00 . The fourth column of p-values reports test statistics for $\mathrm{P}=\mathrm{O}$; because of the coding of the pre-1981 data, this hypothesis could not be tested using the 1979:03 and 1980:03 datasets. The fifth column reports the p-values for the four multinomial tests listed, all of which are 0.00 , and the final column reports the $\mathrm{A}=\mathrm{P}$ test statistics; again, these tests could not be performed on the 1979:03 and 1980:03 datasets.

${ }^{b}$ For the 1981:09 dataset, the model did not converge for the $M(D)=N$ test. 
Figure 1 - Transition Rates into Employment

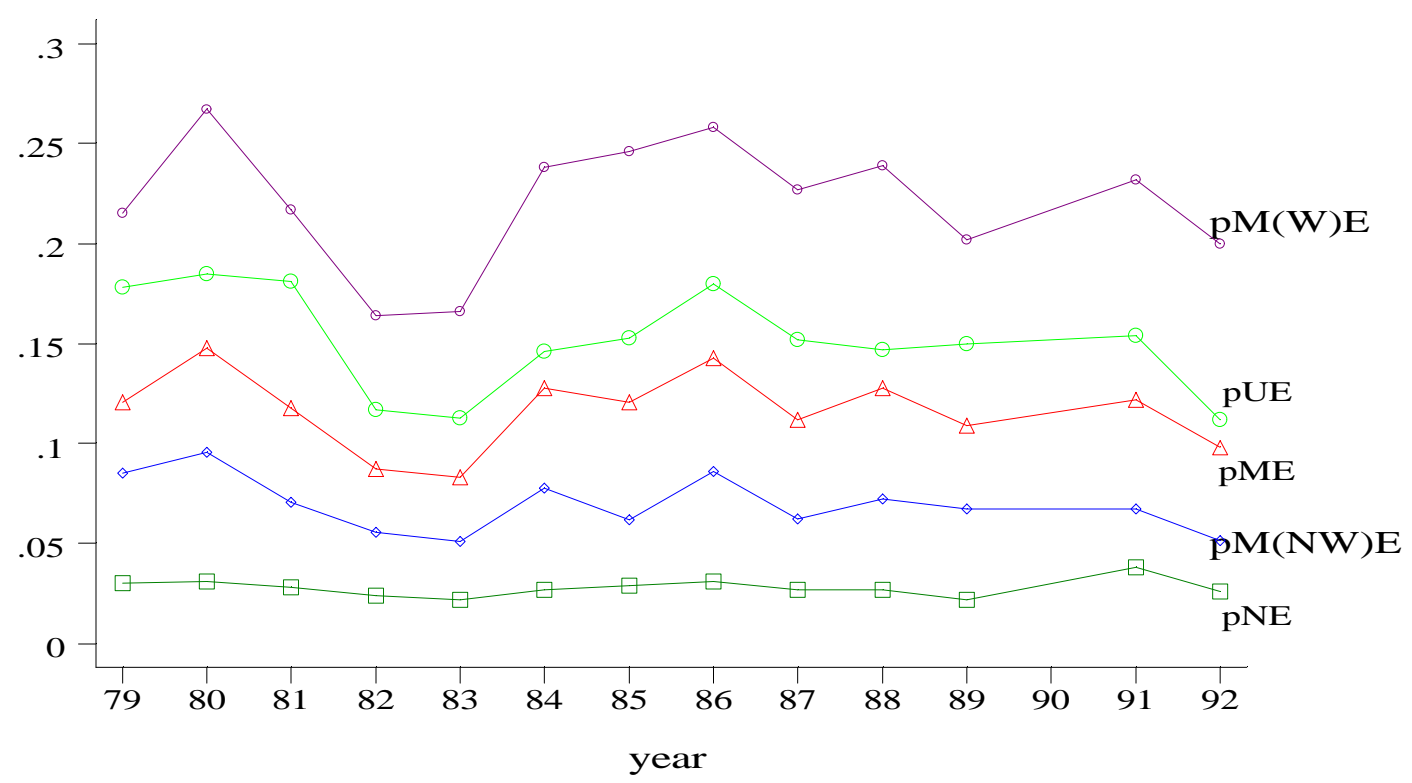


CILN Working Papers (downloadable)

wp43 John Flemming John Micklewright

Income Distribution, Economic Systems and Transition

wp42 John Micklewright Kitty Stewart

Is Child Welfare Converging in the European Union?

wp41 W Bentley Macleod

A Note on the Optimality of Bonus Pay

wp40 Xin Meng Robert G Gregory

Impact of Interupted Education on Earnings:

The Educational Cost of the Chinese Cultural Revolution

wp39 Miles Corak

Death and Divorce: The Long Term Consequences of Parental Loss on Adolescents

wp38 Lori Curtis Martin Dooley

Child Health and Family Socioeconomic Status in the Canadian National Longitudinal Survey of Children and Youth

wp37 Heather Antecol

An Examination of Cross-Country Differences in the Gender Gap in Labor Force Participation Rates

wp36 W. Craig Riddell

Canadian Labour Market Performance in International Perspective: Presidential Address to the Canadian Economics Association

wp35 Shelley Phipps

Economics and Well-Being of Canadian Children

wp34 W. Craig Riddell

Measuring Unemployment and Structural Unemployment

wp33 Susan Johnson

Automatic Certification or Mandatory Representation Votes? How the choice of union recognition procedure affects union certification success.

wp32 James Andreoni Eleanor Brown Isaac C. Rischall

Charitable Giving by Married Couples: Who Decides and Why Does it Matter?

wp31 Herb Schuetze Peter Kuhn 
Self-Employment Dynamics and Self-Employment Trends: A Study of Canadian Men and Women, 1982-1995

\section{wp30 Isaac C. Rischall}

The Effect of High School Effort on Future Earnings

wp29 Isaac C. Rischall

The Roles of Education, Skill and Parental Income in Determining Wages

wp28 Isaac C. Rischall

The Value of a Fresh Start: Earnings Persistence and the Migration of Single Mothers 
wp27 Martin Browning Tom Crossley

Shocks, Stocks and Socks: Consumption Smoothing and the Replacement of Durables During an Unemployment Spell

wp26 Heather Antecol Kelly Bedard

Against All Odds: The Surprising Labor Market Success of Young Mexican Women

wp25 Heather Antecol

Why is there Inter-Ethnic Variation in the Gender Wage Gap? The Role of "Cultural" Factors

wp24 Martin Browning Tom Crossley

Unemployment Insurance Benefit Levels and Consumption Changes

wp23 Heather Antecol Peter Kuhn

Employment Equity Programs and the Job Search Outcomes of Men and Women: Actual and Perceived Effects

wp22 Thomas F. Crossley

Firms and Wages: Evidence from Displaced Workers

wp21 Jennifer Stewart Martin Dooley

The Duration of Spells on Welfare and Off-welfare among Lone Mothers in Ontario

wp20 Peter Kuhn Arthur Sweetman

Vulnerable Seniors: Unions, Tenure and Wages Following Permanent Job Loss

wp19 Kelly Bedard

Human Capital Versus Signaling Models: University Access and High School Drop-outs

wp18 Peter Kuhn Arthur Sweetman

Assimilation and Economic Success in an Aboriginal Population: Evidence from Canada

wp17 Martin D. Dooley

The Evolution of Welfare Participation Among Canadian Lone Mothers From 1973 - 1991

wp16 Lori Curtis Martin D. Dooley Ellen L. Lipman David H. Feeny

The Role of Permanent Income and Family Structure in the Determination of Child Health in the Ontario Child Health Study

wp15 LaDonna A. Pavetti

A New Social Contract: Moving to a Work-Based Assistance System

wp14 Gary Burtless 
The Job Prospects of U.S. Welfare Recipients: Lousier Pay but Bigger Earnings Supplements 
wp13 J.B. Burbidge L. Magee A.L. Robb

Cohort, Year and Age Effects in Canadian Wage Data

wp12 Martyn Andrews Alan Harrison

Testing for Efficient Contracts in Unionized Labour Markets

wp11 Herb J. Schuetze

Taxes, Economic Conditions And Recent Trends in Male Self-Employment: A Canada-U.S.

Comparison

wp10 Peter Kuhn

Canada and the "OECD Hypothesis": Does Labour Market Inflexibility Explain Canada's High Level of Unemployment?

wp9 Stephen R. G. Jones W. Craig Riddell

The Measurement Of Unemployment: An Empirical Approach

wp8 Pierre Lefebvre Philip Merrigan Martin Dooley

Lone Female Headship and Welfare Policy in Canada

wp7 Heather Antecol Peter Kuhn

Gender as an Impediment to Labor Market Success: Why do Young Women Report Greater Harm?

wp6 John Myles Paul Pierson

Friedman's Revenge: The Reform of "Liberal" Welfare States In Canada and the United States

wp5 Jeff Borland

Earnings Inequality in Australia: Changes and Causes

wp4 Jeff Borland

Union Effects and Earnings Dispersion in Australia, 1986-1994

wp3 Robert Gregory Boyd Hunter

The Macro Economy and the Growth of Income and Employment Inequality in Australian Cities

wp2 Peter Kuhn

Labour Market Polarization: Canada in International Perspective

wp1 Peter Kuhn A. Leslie Robb

Shifting Skill Demand and the Canada-US Unemployment Gap: Evidence from Prime-Age Men 
Last updated March 27, 2000 